\title{
SUSTAINABILITY OF NON-GOVERNMENTAL ORGANISATIONS DURING CLIMATES OF REDUCED FUNDING: A CASE STUDY OF THE JOHANNESBURG JEWISH HELPING HAND SOCIETY
}

\section{Refilwe Nyandeni, Eleanor Ross}

\section{INTRODUCTION}

\section{POVERTY AND INEQUALITY}

Apartheid radically altered the way that South African society developed and the subsequent policies and legislation of the post-apartheid government have sought to redress the imbalances that this policy created, particularly in terms of poverty and inequality. In South Africa the number of people living in poverty decreased from 53\% in 1995 to $48 \%$ in 2008 as a consequence of economic growth and expanding employment, coupled with government poverty-alleviation initiatives (National Planning Commission, 2011). However, the number of unemployed people increased from 22.9\% in 2008 to 25\% in 2011 (Quarterly Labour Force Survey, 2011).

This anomaly can be explained in terms of structural unemployment, which refers to the overall inability of the economy to provide employment for the total available labour force, even when the economy is at the peak of the business cycle. Structural unemployment also occurs when there is a mismatch between the skills required by employers and those possessed by employees (Kingdon \& Knight, 2005). According to Jammine (cited in Vollgraaff, 2011a:4), this phenomenon is borne out by Statistics SA, which reported that 14,000 jobs were lost in the first quarter of 2011, despite robust economic growth. Moreover, while South Africa is generally categorised as a middle-income country, it is regarded as an extremely unequal society with its Gini coefficient having risen from 0.596 in 1995 to the unacceptably high level of 0.679 in 2009 (Development Indicators, 2009).

\section{SOCIAL POLICIES AIMED AT ADDRESSING POVERTY AND INEQUALITY}

Poverty impacts on the crime rate and adversely affects access to health services, nutrition, education, housing, sanitation and transport. In response to the far-reaching deleterious effects of poverty on many South African citizens, the South African government has developed policies that are aimed at eradicating poverty. In 1994 the Reconstruction and Development Programme (RDP) was initiated and was aimed at meeting basic needs, developing human resources, building the economy, creating jobs, providing land, housing, water and electricity, and expanding communication networks (Aliber, 2003). In 1997 the RDP was mainstreamed through government departments and the Growth, Employment and Redistribution (GEAR) policy was adopted. The intention of the GEAR strategy was to generate economic growth, create employment through a market-based approach and to reduce inflation and budget deficits. However, the adoption of GEAR has been criticised and viewed as a neoliberal policy, which shifts the responsibility for social welfare from the state to individuals (Patel, 2005).

The special allocations for poverty relief, infrastructure investment and job summit programmes were also launched in 1997. In addition, the Poverty Alleviation Fund was established as a system for financing government activities that were not fully provided for in the normal departmental budgeting cycles (Aliber, 2003). The Department of Trade and Industry introduced programmes to support the small and medium market enterprises (SMME) 
sector. An apex lending institution called the Khula Enterprise Finance was established and networks of SMME advice centres were developed (Aliber, 2003).

In addition, South Africa has a developmental social welfare system that aims to alleviate poverty and to address social problems that are related to poverty. Developmental social welfare is guided by the White Paper for Social Welfare (1997), which is the national policy framework that determines the intentions and objectives of South African social welfare. As part of its developmental strategy, the Department of Social Development renders services through three broad programmes, namely social security, social welfare and community development. Social security services provide grants to vulnerable groups as a way of alleviating poverty. Social welfare services are directed at enhancing the capacities of people to address the causes and consequences of poverty vulnerability. Community development workers endeavour to enhance the capacity of communities to respond to their own needs and improve their developmental capacities to address poverty issues through community mobilisation, strengths-based approaches, skills development and income-generating projects (Integrated Service Delivery Model, 2006).

Principles underpinning community development include ensuring sustainability in communities, respecting diversity, addressing structural disadvantage, empowering community members, valuing community resources, skills and culture, ensuring equal participation of all members and building community (Ife, 2002). The various models that are used in community work include community development, social planning, community education and social action (Weyers, 2001).

Ramaphosa (2011:4) maintains that notwithstanding significant progress in terms of policies and legislation, "the social exclusion and marginalisation of millions of people under apartheid has not been reversed". Consequently, in April 2010 President Zuma appointed the National Planning Commission under the chairmanship of Minister Trevor Manuel to explore the challenges to overcoming poverty and inequality. In 2011 the Commission identified nine key challenges, namely high unemployment; poor education; an ailing health system confronted by a massive disease burden; communities divided along racial lines; uneven performance by the public service; the marginalisation of the poor by spatial patterns where many poor black persons live far from economic centres; corruption; a crumbling infrastructure and the fact that the economy is resource-based. These challenges will inform the country's vision and national strategic plan for 2030 to achieve a just and inclusive society as envisaged in the South African Constitution and the Bill of Rights (Ramaphosa, 2011). The plan will also be aligned with the National Growth Plan of the Economic Development Minister, Ebrahim Patel (Vollgraaff, 2011b). Non-governmental organisation (NGOs) will play a key role in the national strategic plan.

\section{FUNDING AND SUSTAINABILITY OF NON-GOVERNMENTAL ORGANISATIONS TASKED WITH ADDRESSING POVERTY AND OTHER SOCIAL ISSUES}

South African social welfare policy rests on a partnership between the state and civil society. The actors involved in this partnership include faith-based organisations (FBOs) and other nongovernmental organisations (NGOs). The relevance and role played by FBOs and NGOs in poverty-alleviation strategies is well recognised by the post-apartheid government (Patel, 2005; Van der Merwe, Swart \& Hendricks, 2009).

Hence the Welfare Laws Amendment Act 106 of 1997 was passed to provide financial awards to FBOs and NGOs that render developmental social welfare services. Some of these 
organisations receive funding from the government through the National Development Agency and the National Lottery Distribution Trust Fund. Other NGOs receive both donor funding and government funding. The Taxation Amendment Act of 2000 was also passed to create favourable tax regimes that reduce the income taxes on NGOs and exempt donors from donations tax. The funding provided by the state is essential, as it determines the sustainability of services provided by NGOs and their ability to deliver programmes, build staff capacity and ensure the quality of services provided to community members (Patel, 2005; Swilling \& Russell, 2002).

However, the funding model for NGOs would appear to be inadequate. In support of this statement, Philp (2009:1) reported that "more than 500,000 needy South Africans, many of them women and children, could be plunged into further desperation as the country's charities battle a funding crisis". Sibanda (2009) conducted in-depth interviews with key informants from 15 NGOs located in various service fields in Johannesburg. She found that the main challenges were insufficient and at times delayed funding by state departments, which prevented them from offering their staff market-related salaries and engaging in entrepreneurial activities on a scale sufficiently extensive to wean them from an over-reliance on donor funding.

Moreover, despite the current recession and increases in electricity and food prices, there has been no concomitant increase in the budgets for organisations caring for the elderly and disabled in the past four years. Consequently, there have been several fires at old-age homes, which have killed more than 60 people since 2007, attributed largely to lack of funds to maintain aging infrastructure in safe working order (Du Plessis, 2011a).

There have also been numerous complaints regarding the allocation of funds, unspent funds and the time taken by the National Lotteries Board (NLB) to distribute funds to successful applicants, prompting a call for amendments to the Lotteries Act (Chauke, 2011). Matters came to a head in 2010, when the National Association of Welfare Organisations and NonGovernmental Organisations and the NG Social Services Free State took the Department of Social Development to court to compel it to pay subsidies owed to care centres run by nonprofit organisations. In June 2011 the Free State High Court ordered the Department to rectify the funding policy, which it declared unconstitutional (Du Plessis, 2011b). At the time of writing this article the case had been referred to the Supreme Court of Appeal. More recently, in another case the Supreme Court of Appeal dismissed an appeal by the NLB against the decision of the Western Cape High Court overturning its refusal to approve grant applications by registered charities the South African Education and Environment Project and the Claremont Methodist Church Social Impact Ministry (Sikhula Sonke) (Bick, 2011:2).

Although many NGOs representing various communities have struggled to survive in the current economic climate of reduced government subsidies and reduced donor funding (Patel, 2005), organisations such as the Johannesburg Jewish Helping Hand Society (JJHHS), which has been operating for over 120 years, have managed to sustain themselves without undue reliance on the state and continue to work to alleviate poverty and social problems. The purpose of the research was therefore to explore the factors contributing to the sustainability of this organisation. Specific objectives were to understand the values, principles and social welfare theoretical paradigms, as well as the human resources and funding strategies, that underpin social service delivery and poverty alleviation and which promote sustainability in the JJHHS. It was envisaged that information gathered could potentially be used to inform management on the sustainability of FBOs in difficult economic times and thereby empower other organisations 
to be self-reliant. It was also felt that the research could potentially fill part of the gap in the research literature on sustainability strategies of faith-based NGOs.

\section{METHODOLOGY}

\section{RESEARCH DESIGN}

The research took the form of a case study of the Johannesburg Jewish Helping Hand Society (JJHHS) and was located within a qualitative paradigm. According to Algozzine and Hancock (2006:9), a case study is a type of qualitative research which involves the "intensive analyses and description of a single unit or system bounded by space and time". A "qualitative research approach is based on the interpretive perspective, which states that reality is defined by the research participants' interpretations of their own realities" (Williams, Unrau, Grinnell \& Epstein, 2011:53).

\section{SAMPLING PROCEDURES}

The sample was composed of 15 key informants within the Johannesburg Jewish Helping Hand Society (JJHHS). The participants were representatives of various divisions within the welfare system, and were recruited via purposive sampling. A limitation of the sample was that the key informants were selected by the General Manager, which might have introduced a degree of bias into the study. Also, the small non-probability sample precluded generalisation of the findings to other Jewish welfare communities in South Africa. However, the advantage of this method was that the General Manager was able to identify persons who had in-depth knowledge of the organisation and all the aspects targeted in the study.

\section{RESEARCH TOOL}

A semi-structured interview schedule was developed for the study and explored the following aspects: demographic details of participants; nature of services; values; paradigms of social responsibility; community development principles; human resources; and funding. The research tool was pre-tested on one service provider from the Johannesburg Jewish Helping Hand, who was not included in the final study. After that necessary amendments were made.

\section{DATA COLLECTION}

Data were collected through individual interviews held at the specific place of employment of each participant. These interviews were flexible as they enabled the researcher to probe more deeply onto issues of interest and clarify matters that arose within the interview. Data collection continued until data saturation was achieved, i.e. no new themes were articulated by participants. Kelly (2006:372) defines saturation as "the condition of an interpretive account where the account is richly fed by the material that has been collected, at least to the point where the researcher can intuitively say: 'I have thoroughly explored the data and have acquired a satisfactory sense of what is going on". There is the possibility that some participants may have furnished socially desirable responses, particularly in view of the fact that the researcher was from a different religious and cultural community.

\section{DATA ANALYSIS}

The data were analysed using thematic content analysis, which entails classifying of textual material and reducing it to relevant and manageable data (Weber, 1990). The five-step approach to interpretive data analysis was adopted from Terre Blanche, Durrheim and Kelly (2006). In step one, namely familiarisation and immersion, the researcher (the first author) familiarised herself with the data, and immersed herself in it, making notes and brainstorming. 
The second step involved inducing themes, whereby the information was organised based on the principles that underpinned the material. Step three entailed coding the information, whereby the researcher grouped certain kinds of information in order to compare responses from participants. Step four involved identifying sub-issues and themes that emerged from the coding and comparing the information. In step five, which was the final step, the information was interpreted and meaning was attached to the data.

In order to enhance the trustworthiness of a qualitative data analysis, the following concepts were taken into account, namely credibility, dependability, confirmability and transferability. To ensure the credibility of the research project, the researcher interviewed key informants who were service providers and were well-informed about the operations of the organisation where the study was conducted. Efforts were made to enhance dependability by posing the same questions to all participants and by the researcher conducting all the interviews herself. Confirmability was enhanced through correspondence checking as recommended by Pretorius and De la Rey (2004), whereby the researcher's categorisation of themes was checked by an independent researcher for correspondence. However, in terms of transferability, the small nonprobability purposive sample that was used in this research precluded generalisation of these findings to other situations. Moreover, in analysing the themes articulated by participants, a limitation that emerged was that some themes were only expressed by one or two participants, which could be related to the small sample size.

\section{ETHICAL CONSIDERATIONS}

In order to comply with the requirements for ethical research and to protect the rights of research participants, the following ethical principles were taken into consideration, namely informed consent; voluntary participation; confidentiality; non-maleficence; feedback to participants; addressing a research issue of social value to society; and obtaining ethics clearance from the relevant university ethics committee.

\section{RESULTS AND DISCUSSION}

\section{THE JOHANNESBURG JEWISH HELPING HAND SOCIETY (JHHHS)}

When gold was discovered in Johannesburg in 1886, many people migrated to this country to find opportunities for employment and to seek their fortunes. Amongst the many who migrated to South Africa were Jewish people. As is the custom wherever a Jewish community is established, a burial society responsible for attending to Jewish ritual burials of community members was established and this society, called the Chevrah Kadisha, also known as the Johannesburg Jewish Helping Hand Society (JJHHS), was established in 1888. The JJHHS soon assumed responsibility for providing for the welfare needs of its members and developed various services and programmes.

\section{NATURE OF SERVICES PROVIDED BY THE JJHHS}

The organisation has seven different divisions that provide various services.

\section{Community Social Service}

This division provides counselling services to individuals and families, and addresses issues such as domestic violence, physical and mental health, trauma debriefing, marriage preparation, marriage counselling, divorce counselling and divorce mediation. This division is an accredited child protection agency and offers educational programmes, group support, safe housing, accommodation, and access to legal and financial assistance. In addition, outreach programmes 
provide resources for previously disadvantaged communities, e.g. assisting learners in local public primary schools with English language skills.

\section{Selwyn Segal Centre}

The Selwyn Segal Centre is a residential facility for 180 people with intellectual disabilities. A day-care programme is offered for people with mental illness, who come during the week and participate in the programmes together with residents at the Selwyn Segal Centre. This division provides counselling services and runs social skills groups for both residents and day-care attendees. In addition, there is a protected workshop where attendees work and earn wages. There is also a farm called Kibbutz Lubner, which has a protected workshop and residential facility for people who are unable to work in the open labour market. The Outreach project run by the Selwyn Segal Centre is aimed at enhancing the functioning and skills of intellectually and physically disabled youths and adults in Alexandra and surrounding areas through occupational therapy workshops.

\section{Sandringham Lodge}

This is a residential mental health facility for people with psychiatric illnesses, which offers psychotherapeutic services, group therapy and a psycho-social rehabilitation programme. Staff members work within a multidisciplinary team with nurses, doctors, social workers, a psychiatric nurse, a psychiatrist and psychologists. Daily activities are arranged for the residents such as arts and crafts, among others.

\section{Sandringham Gardens}

This old-age home has a hospital section for rehabilitating elderly persons with acute or chronic illnesses, as well as a unit for persons with dementia. There is also an assisted living section as well as an independent living section. In addition, the home has a social work department that is responsible for intake and conducting assessments. Volunteers befriend the residents and visit on a weekly basis.

\section{Our Parents' Home}

This division is a second home which provides residential care for the aged. The residents receive various services offered by physiotherapists, social workers, doctors, and nurses. The home also provides support for families that experience difficulties adjusting to placing their parents in the home. The residents vary from ill residents who need constant care to those who are able to function more independently. The division also has a unit for residents who have been diagnosed with dementia. The residents participate in a programme of varied daily activities, such as bingo, lectures and outings.

\section{The Second Innings Programme}

The Second Innings Programme is a project that aims to provide opportunities for senior citizens to engage in meaningful community activities and empower historically disadvantaged communities by providing them with education, training, resources and capacity building.

\section{Arcadia Children's Home}

This home accommodates 30 children who have been removed from their families by the courts. An after-school programme including supervision of homework, is provided for children who are still in the court procedure. The home also has an aftercare programme for children who have completed schooling or have proceeded as far as they can in their schooling. They are assisted to acquire tertiary education, as well as with accommodation and financial assistance. The organisation is also involved in training child and youth care workers within the 
courses run by the National Association for Child and Youth Care Workers. In addition, the Manager has had partnerships with other homes, where she has acted as a consultant to managers and assisted them to develop their skills.

\section{PROFILE OF KEY INFORMANTS}

All the representatives who participated in the study were female. Not surprisingly 11 were from the Jewish faith. Twelve of the 15 were qualified social workers, with only one being a social auxiliary worker and two being psychologists. Five of the participants were from the Jewish Family Services organisation; three from Selwyn Segal Centre; two from Sandringham Lodge; two from Sandringham Gardens; two from Our Parents' Home; and one from Arcadia Children's Home. A limitation of the study is that no question was included on the participants' position in the organisation/division.

\section{EMPLOYMENT CREATION AND POVERTY ALLEVIATION}

The organisation has developed a programme called the World of Work, which is run by the human resources department. People are helped to obtain employment in the open labour market, or work within the organisation as receptionists, carpenters, electricians, filing clerks or laundry assistants, and are paid a salary. The organisation also has a protected workshop called Kadima, where people with mental illness work and receive a stipend. As mentioned earlier, the Selwyn Segal Centre also had a protected workshop for persons with an intellectual handicap. These employment opportunities represent a form of poverty alleviation or "tzedoka". According to Goldstein (in Goldstein \& Mandela 2003:181-182), the word tzedoka "derives from the Hebrew word tzedek, which means justice...Tzedoka is not only about a personal discretion; it is also about the obligation and responsibility to deal effectively with poverty". Goldstein explains that the highest level of charity involves providing someone with employment or helping people to establish their own business.

\section{SERVICE FEES}

Representatives who were interviewed reported that five of the six divisions in JJHHS charged fees for services. Only the children's home did not charge fees for its services. However, their fees were calculated on a sliding scale depending on what an individual could afford. The disability grants of some of the residents were used in the case of persons who did not have families who could pay their fees. People who could not afford to pay the full price for services still received comprehensive services.

\section{SUCCESSES AND CHALLENGES IN SERVICE PROVISION}

Table 1 highlights the successes and challenges in service delivery identified by participants. The aspect mentioned most frequently as a form of success was the fact that the two old-age homes were viewed by residents as homes in the true sense of the word, rather than institutions. 


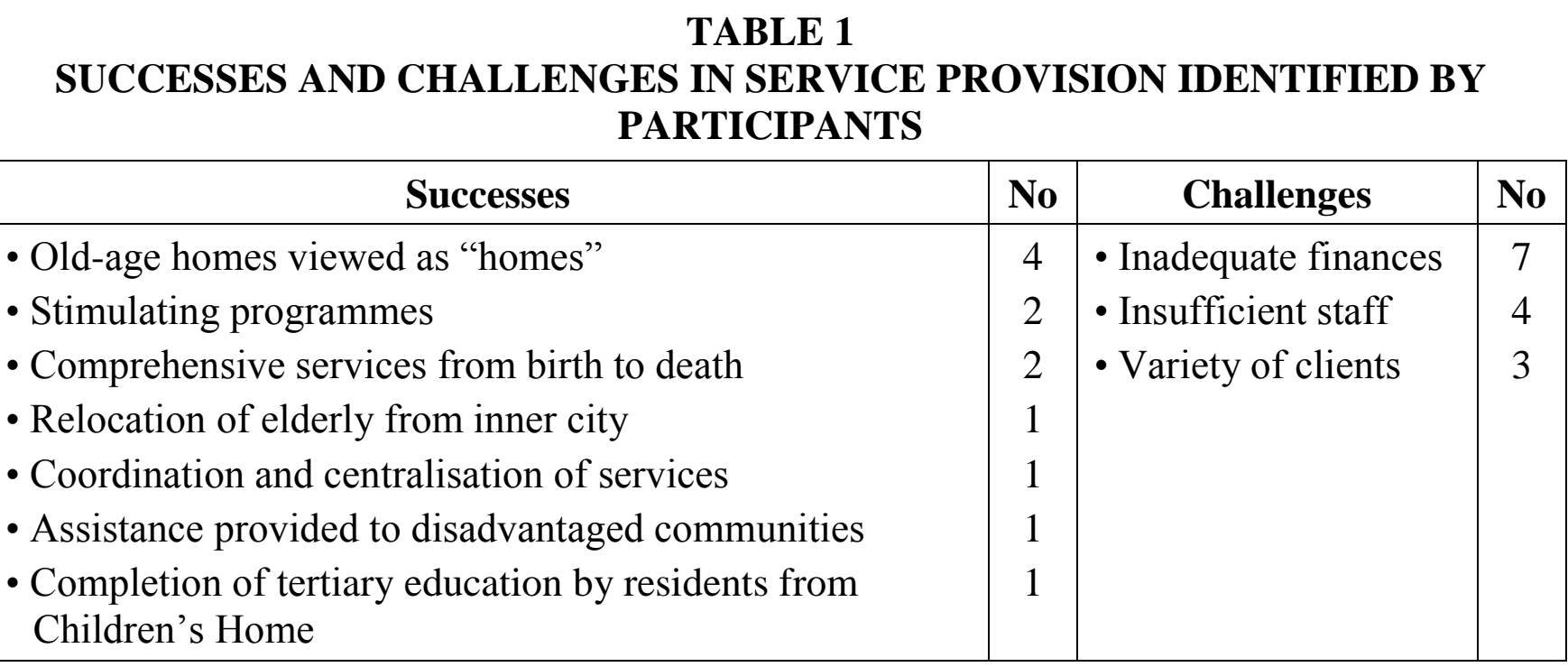

The most important challenge they faced was related to financial services. The organisation was mainly donor based, and there had been a decrease in the financial donations, which they attributed to the current economic recession. One of the participants explained: "When times are difficult in the open labour market, we have an increase in the number of people needing our services. We cope with it, but it is a challenge". This finding was consistent with Philp's (2009) contention that South African welfare organisations were battling a funding crisis. Insufficient staff was also a challenge. In fact, the organisation had been compelled to cut down on staff members in some divisions because of financial factors. This theme was encapsulated in the response of one participant, who commented: "The two impact on each other: if we have more money, we would have more staff; if we had more staff, the services could be better. We are limited by our lack of human resources, and that is because of financial limitations".

\section{VALUES AND PRINCIPLES UNDERPINNING SERVICE DELIVERY}

\section{Jewish values}

\section{Chesed (loving kindness)}

Nine participants articulated the view that the Jewish value that influences the action of serving community members was chesed, which means "loving kindness". One was expected to be kind and build human capacity, and these values would seem to embrace social work values of self-determination, empowerment and capacity development (DuBois \& Miley, 2011). According to Goldstein (2010), the efforts to create a welfare system were influenced by the religious value of rendering social justice to vulnerable groups, which include the poor, widowed, orphans, disabled and the aged. Justice entails alleviating the suffering of these groups by being compassionate (Goldstein, 2010). He explains that Jewish laws require that people involve themselves with the welfare of society by actively contributing to their communities (Goldstein \& Mandela, 2003). He further explains that the action of contributing is not merely being charitable, but involves fulfilling basic justice. It involves alleviating poverty at a private and community level (Goldstein \& Mandela, 2003). This theme was reflected in the following response: "The big thing that the organisation focuses on is the principle of chesed, which means loving kindness...the principle is that we are kind to people...people are given ample chances. Being compassionate and caring about people". 


\section{Setting limits and encouraging responsibility and initiative}

Although being kind and loving towards others was regarded as an important value, there were limits and boundaries placed on this value. People were encouraged to take the initiative and try to be independent, which is related to the social work value of empowerment. Empowerment in social work is concerned with increasing personal and interpersonal power, so that individuals can take action to improve their life situations and reduce their dependence on external sources (Kirst-Ashman, 2007). One participant emphasised the importance of such boundaries in the following statement: "When we say loving kindness, it doesn't mean that all loving is all giving. There is a time when one needs to take responsibility."

\section{Respect for the elderly}

Two participants highlighted the Jewish value of respecting and honouring the elderly. This value corresponds with the Older Persons Act (2006), which aims "To deal effectively with the plight of older persons by establishing a framework aimed at the empowerment and protection of older persons and at the promotion and maintenance of their status, rights, well-being, safety and security".

\section{Family preservation}

The value of preservation of family derives from the importance of keeping peace in Jewish homes, which is referred to as "shalom bayit". However, this value presented ethical dilemmas in cases of domestic violence. As one participant put it, "It's tricky, if we can help create changes so that the families will be preserved, that would be our first choice. But if we can't, then we would have to try for the safety of women and children".

Similarly, the White Paper for Social Welfare (1997:60) stipulates that family and child welfare services aim to "strengthen, preserve and strengthen families so that they can provide a suitable environment for the physical, emotional and social development of their family members".

\section{Social work values}

Other values that were deemed important in this organisation were social work values such as being non-judgmental, upholding confidentiality, and respecting the worth and dignity of clients. Following legislation was also regarded as important. For example, the Children's Home needed to ensure that it met the standards prescribed by the Children's Act. The strengths-based approach was also used in service provision as reflected in the following verbatim response: "We follow a strengths-based approach, instead of the medical model which focuses on the child's pathologies". Saleeby (2006) advocates for the adoption of a strengths' perspective when working with clients, as focusing on strengths instead of weaknesses helps build the capacities of clients.

\section{Utilising local resources}

The organisation not only made much use of its own resources, but also utilised state medical resources such as hospitals and clinics when necessary. Since there were different divisions within the organisation, referrals could be made within the organisation. Volunteers served as an important resource, as some volunteers befriended the residents in the residential facilities. Professional volunteers such as doctors, a skin specialist, a dentist, a psychiatrist and an optometrist provided free medical services. The organisation also received donations such as clothing, furniture, art supplies, books and physiotherapy equipment. In line with these findings, Ife (2002) indicates that utilising resources that are available in the community enables the community to be self-reliant and sustainable. 


\section{Utilising skills of community members}

Participants indicated that they utilised people who volunteered their time and skills to assist the organisation. These volunteers included professionals such as doctors, music teachers, hair stylists and other professionals who offered their services on a pro bono basis. The skills that the residents possessed were also utilised; for example, some residents helped in the dining hall. The old-age homes had residents committees which liaised with management to bring the concerns of the residents to their attention. Some of the senior citizens ran the bingo programme, while others ran the library and the book club. Some of the elderly visited local schools, where they taught the learners and helped with language enrichment and homework. The divisions also endeavoured to enhance the skills that clients had; for example, clients who showed an interest in art had art classes available to them.

This approach enabled elderly residents to feel that they were making a positive contribution in the homes in which they lived and reduced feelings of helplessness and powerlessness. According to Kowalski and Leary (2004), the opportunities that allow the elderly to feel that they have control over their personal lives leads to improved physical and psychological outcomes. This theme was encapsulated in the following response: "We try to empower them as much as possible, but it's quite difficult, because there is kind of a lethargy in terms of the elderly and it's due to real factors because they are elderly. Most of them are very frail and we try to empower them and take them away from learned helplessness to learned helpfulness."

\section{Human rights}

Ten participants mentioned that the organisation respected the rights of clients to be independent, their right to dignity, confidentiality, their right to have their psycho-social, spiritual and physical needs met, and their right to receive appropriate services. Four of the participants indicated that clients were educated about their rights as well as their responsibilities. The parents of clients with a mental handicap were also educated about the clients' right to be involved in relationships, even though they might have a low mental age. One participant commented: "Jewish rights are human rights," meaning that the Jewish religion is concerned with promoting the human rights of people. This comment was consistent with the assertion by Goldstein (in Goldstein \& Mandela, 2003) that respecting the dignity of others is important in Jewish law.

\section{Jewish identity}

Nine participants explained that Jewish identity was maintained in the organisation by ensuring that the residential areas were kosher environments; there was a synagogue on the premises; rabbis were available; and Jewish festivals and holidays were observed. There were mezuzot on the doors; these are small boxes containing Jewish prayers for protection of the inhabitants. This theme was reflected in the following response: "It's maintained firstly by the fact that this is a Jewish organisation...with Jewish clients...Jewish religion is very much promoted...we ensure that the Jewish identity is kept on whatever functions ... we have...we make sure that it is strictly according to Jewish laws and values and tradition."

One of the participants indicated that on the Sabbath candles were lit, they recited brochas (blessings), and the residents were given small glasses of wine with their meal. "There is a lot of Judaism in the home, non-kosher food is not allowed inside the home, we have two rabbis come twice a week to give lectures on Jewish topics, a rabbi who comes daily."

One participant maintained that although this was a faith-based organisation, the counsellors were not there to judge whether people practised conservative, ultra- or orthodox Judaism, 
thereby demonstrating the social work value of "starting were the client is at" (Shulman, 2006). However, there was a rabbi available for clients to consult. Another participant emphasised that the services of the JJHHS were not designed to promote the Jewish religion, but to care for families in need and to serve the disadvantaged members of the community.

\section{Integrating religious values into social science theory}

Seven participants were of the opinion that service delivery was influenced by both religious values and social work theory, which enriched rather than contradicted each other. The viewpoint was articulated that at times there might be dilemmas, which also arose in social work practice. The example was given of termination of life support, which would require close consultation with religious authorities as saving some one's life was regarded as important in the Jewish religion. This theme was expressed in the following comments: "Two go hand in hand, we are an orthodox Jewish home, but a lot of the social work basic principles are ...the same as religious principles... respect for human dignity, appreciation" and "Our services are structured in such a way that they include social work principles and cultural beliefs and religion... particularly in the social work area, we uphold the code of conduct. We have a legal obligation and our guiding principles come out of Judaism".

One participant shared the fact that in the past it had been difficult for her to integrate the two value systems, but recently she had been able to do so more easily. "We were working with rabbis in the past; it was difficult to educate them and get them to challenge some of their views. We have been working with religious groups so that they can educate us and we can also educate them and see how we can put it together".

Another participant indicated that even though they used both religious and social work principles, they were mainly guided by social work theory, because they were working as professional social workers. However, another participant acknowledged that it was challenging to merge the two value system at times, as she was not from the Jewish faith. "It can be frustrating when something binds you not to do something because of Jewish laws". A non-Jewish participant indicated that when there was something that she needed to know regarding Jewish laws and customs, she asked fellow Jewish workers. "Because I'm not Jewish, my work is not based on religion; I operate from a clinical perspective; I respect religious law".

In line with these findings, Canda (2006) asserts that research has shown that spirituality is a strength that clients use in achieving a sense of personal and social wellbeing and it can be helpful for social workers to integrate spirituality into the helping process.

\section{PARADIGMS OF SOCIAL RESPONSIBILITY UNDERPINNING SERVICE DELIVERY}

All the participants reported that they employed a developmental approach when working with clients. Two participants mentioned that their divisions operated within a medical model, but they had shifted away from it towards a developmental perspective. Those clients who demonstrated a higher level of functioning were encouraged to live independently and make their own decisions. One participant explained that the clients' skills were harnessed and developed, depending on their age and health, as some clients who presented with mental illness could maintain a routine, while others could not.

Another participant mentioned that some workers in the Children's Home had undergone training in developmental assessment, which focused on using a strengths-based approach that endeavoured to harness the strengths of the child, instead of using a medical model which 
focused on the pathologies of a person. Five participants reported that they tried to deinstitutionalise the residential areas so that such residences become a home for clients and not an institution.

One of the participants explained that they adopted a developmental paradigm when working with people with intellectual disabilities. They were aware of their limitations, but also considered what the clients were able to achieve. The residents in the old-age home were encouraged to take responsibility for their daily activities. Even though some of the elderly people went through a cycle of being ill and frail and subsequently regained their health before lapsing back into ill health, they were encouraged to be independent for as long as possible. These responses could be regarded as elements of the social developmental paradigm. Bhagwan (2010) asserts that both social development and spirituality have the same values of human dignity, equality, social justice and peace.

\section{COMMUNITY WORK MODELS}

Seven participants mentioned that they employed the community development model, the social planning model and the community education model, which were all applicable in their respective settings. They endeavoured to use the community development model in order to involve clients. One participant explained that the social planning model was used in a community project for survivors of the holocaust, but they tried to involve the community members as much as possible in planning for the programme.

Seven participants reported that they used the community education model mostly in order to educate community members on various topics. One of these projects involved creating awareness amongst the community members about mental illness in order to reduce the stigma attached to the condition and to make them aware of the services that were available to them. Another programme was called the Love Should Not Hurt, which aimed to educate Grade 9 learners about having healthy relationships and how to identify abusive relationships. Other educational programmes included topics that were relevant to an aged population, such as Parkinson's disease and dementia.

\section{COMMUNITY WORK PRINCIPLES}

\section{Partnerships}

Participants informed the researcher that the organisation had an informal partnership with a religious Jewish organisation that provided talks on religious topics. The organisation also enjoyed a cordial relationship with the Departments of Health and Social Development. In addition, the JJHHS had previously entered into a partnership with a Children's Home in Soweto whereby they trained care workers in the home. The organisation also partnered with schools. In one of these partnerships elderly people helped the children with language enrichment and homework, which helped the older people feel that they were making a positive contribution in the community while at the same time benefiting the learners.

\section{Sustainability}

Table 2 indicates the factors that were perceived to contribute towards sustainability of the JJHHS. 
TABLE 2

FACTORS THAT CONTRIBUTED TO THE SUSTAINABILITY OF THE ORGANISATION

Factors contributing to sustainability of the JJHHS

Number of

participants

- Soliciting donations and harnessing community support

5

- Enlisting financial contributions from family members

- Pro bono services

5

- Adapting to difficult financial times

- Showing appreciation to community members and volunteers

- Compliance with funding requirements of Department of Social Development

\section{Soliciting donations and harnessing community support}

Five participants indicated that the community members' commitment to donating to the organisation helped to ensure the sustainability of the organisation. This theme was reflected in the response of one participant who commented: "I am not Jewish and I have never seen an organisation like this or a community like this who stands together, who pools resources and who looks after each other... and I think that is really a contributing factor as to why the successes of Arcadia and this organisation are. They are because of this community, its support and its working together. It's quite an eye opener".

\section{Enlisting financial contributions from family members}

Five participants explained that in order to ensure the sustainability of the organisation, family members had been asked to take responsibility and contribute to the care of their family members. The organisation also determined whether a person could afford to pay for services and payment was related to what they could afford. The organisation also tried to ensure that people did not abuse the services. "It's a combination of a business model and a welfare model...in order for these services to be sustainable, they have to take on a business approach...they have to make smart decisions as well...we can't just base all our decisions on clinical and welfare type of thinking. There has to be a combination of: is this feasible, practical. We need to determine who is really in need of those services".

The sliding fee scale was also one of the ways of ensuring sustainability of programmes, and people were encouraged to pay for the services they received. "There is value ... if they pay for services as opposed to just receiving". In this respect, Pinch (1997), maintains that commercialisation of services is one of the important changes affecting welfare states. However, the charges are usually less than full market value. Those who advocate charging for services argue that if people do not pay for services, they are more likely to misuse them. Others argue that charging services exerts discipline upon service providers to meet their customers' demands.

\section{Pro bono services}

Three participants indicated that the services they received pro bono enabled them to use their funds for other needs. This theme was encapsulated in the following verbatim response: "Trivial as it seems, but having a child's hair cut is an expenditure, and if you have people doing it for free of charge, it's just that much less that gets added on to our budget." 


\section{Harnessing the sense of Jewish identity and religious value system}

Two participants commented that the hardships that Jewish people had experienced had contributed to their efforts to help take care of each other, build the community and sustain the organisation. The religious values contribute to this ethos, as people were expected to give a certain amount of their income and money to charity. The following responses embodied this philosophy: "The Jewish community feels a huge responsibility to itself and to look after members of the Jewish community, it's an important overriding principle in our religion. It's a community-run organisation - we depend solely on community support. The government no longer subsidises our division. Most of the budget was from the community. Unfortunately in terms of financial...there has been a lot of poverty amongst the Jewish population." Another participant commented: "You have to give a certain amount of your income and money...you need to give to charity and give to help others,...it's kind of engraved in who they are, even in their children ... the Jewish community is very big on donating". In this respect Nielsen (1972) asserts that some funders are motivated to donate funds because of their religious convictions and an intense sense of social responsibility.

\section{Adapting to difficult financial times}

Two participants reported that the organisation had experienced financial difficulties and had been compelled to adapt and make some changes. The changes included harnessing the sense of Jewish identity to increase material and non-material donations, cutting back on unnecessary expenditure, and retrenching staff.

\section{Compliance with funding requirements for the Department of Social Development}

One participant informed the researcher that having a positive record with the Department of Social Development was one of the ways that sustainability was maintained for the Children's Home. Providing the Department with the business plan, statistics, reports and other information required helped to ensure that the per capita funding was received.

\section{Showing appreciation to community members and volunteers}

One participant mentioned that the Children's Home sent letters of appreciation to community members who provided them with resources. It was reported that in previous years there had been regular end-of-year functions to acknowledge and thank volunteers. However, as a result of the economic recession it had become necessary to cut back on some of these functions.

\section{EMPOWERMENT}

The Children's Home empowered residents by holding cottage meetings, where staff and children's representatives raised issues they needed to address, such as bullying. The Community Social Services held educational talks and programmes during the 16 Days of Activism against the Abuse of Women and Children. There were also efforts to empower individual clients based on the client's goals. Support groups were one of the ways through which clients became empowered, as they were afforded the opportunity to share their experiences and support one another. These activities appeared to be consistent with approaches to empowerment advocated by Adams (2003), who explains that empowering people involves having dialogue between people, where people do not impose their own ideas on other people.

\section{HUMAN RESOURCES}

All the participants emphasised the importance of human resources in sustaining the JJHHS and enabling the organisation to achieve its goals and objectives. 


\section{Professional staff}

The Johannesburg Jewish Helping Hand Society employed qualified youth care workers, social workers and nurses, occupational therapists and a psychologist.

\section{Volunteer programme}

It was also reported that JJHHS had a volunteer programme for people who were interested in volunteering within the organisation. The volunteers included both professional and nonprofessional volunteers. In terms of selection criteria, the volunteers were required to attend nine training sessions over a period of three months and be able to commit themselves to the tasks to which they had been assigned. They also received regular supervision and were required to sign confidentiality clauses. Volunteering was seen as an act of giving to the community; hence the volunteers did not receive payment for their services.

\section{Opportunities for professional development}

Five participants were of the opinion that the training, professional development opportunities and supervision that staff received were some of the factors that sustained staff morale. Staff members arranged journal clubs and interagency meetings, where experts were invited to give talks on particular topics. These opportunities enabled the workers to keep abreast of new developments in their field of work and to interact with each other. The rabbi also gave talks to social workers once a month on topics related to Jewish values.

\section{Market-related salaries}

One participant explained that the organisation offered salaries that were market-related in order to retain staff. Two other participants indicated that although it was not difficult to retain staff, those staff members who obtained better salary offers in another organisation sometimes resigned to work in that organisation.

\section{Support and recognition}

One participant mentioned that giving staff members praise and recognition was one factor that kept staff morale high. Another participant commented that support from peers and management enabled her to sustain her working morale. One participant said that they did not have difficulty retaining staff as the workers loved the environment in which they worked.

\section{FUNDING}

The Revenue Department was responsible for raising funds and allocating resources to different divisions. The annual welfare budget was in excess of R22 million per annum. The organisation's funds were mostly derived from community members, while some funding was obtained from the government subsidies for certain divisions. Some finances accrued from the disability grants and pensions of the residents; however, these contributed very little revenue. Most funders did not set conditions for funding, while some funders donated to particular divisions. Fund-raising events were planned throughout the year and the organisation had ongoing relationships with certain donors who donated on an annual basis. In discussing the role of the Revenue Department, one participant commented: "Their main focus is to continue to get funds and donors to donate ... Our job is to run the facility and ensure that the clients have the services they need".

It was reported that the government subsidy had been withdrawn from Our Parents' Home and Selwyn Segal Centre. The Centre only received a grant for the outreach programme run at a school for intellectually challenged individuals. Besides the withdrawal of these subsidies, the organisation had been facing financial challenges exacerbated by the current economic crisis. 
One participant indicated that donors had not been able to donate as much as previously and others were no longer able to make any donations. Three participants explained that immigration of some community members had resulted in a decrease in the number of people who donated to the organisation.

Tracy (2002) explains that the larger an organisation is, the more likely it will have formal and comprehensive financial budgeting processes in placed. Unexpected developments may not be included in the budget and require adjustments to be made for such developments. The JJHHS also had to make changes to address the financial challenges it had experienced. For example, residents were not taken on as many outings as they had previously, and refreshments for certain meetings were cut back. One participant indicated that they tried to make use of speakers who would not charge fees to present their talks. Another participant emphasised that in order to ensure sustainability of certain programmes like some of the conferences, a fee was charged so that the programme could continue. Moreover, some staff members were retrenched as a result of the organisation's financial difficulties.

\section{CONCLUSIONS AND RECOMMENDATIONS}

The main conclusions drawn from these findings were that the Jewish values of chesed (loving kindness), the importance of community life, and the notion of giving to charity underpinned the actions of addressing poverty and other social issues. These values also contributed to sustaining this organisation, as community members donated funds and tangible goods, and made their skills available to serve community members in need. As a well-governed organisation, the JJHHS can serve as a role model for other community organisations seeking options for sustainability during difficult economic climates.

It is recommended that NGOs foster good governance and risk management by acting as stewards, wisely conserving scarce resources, avoiding unnecessary expenditures and complying with funding regulations. Good relationships need to be built with donors and fundraising needs to be an on-going activity. It is also recommended that NGOs draw upon community work principles as well as the spiritual, cultural and religious values to involve communities and encourage community members to donate material, financial and personal resources to promote the sustainability of NGOs. In South Africa the concept of Ubuntu, or community solidarity, and other religious values could be harnessed to create greater community involvement with welfare programmes and thereby promote the sustainability of NGOs. It is further recommended that quality staff be retained through staff development, enhancing work conditions, and showing appreciation for individual contributions, thereby promoting job satisfaction. On a practical level social workers need to harness the skills, knowledge and experience of older persons in assisting children with homework. They also need to make a greater use of professional persons who volunteer their services on a pro bono basis. In addition, it is recommended that the Department of Social Development re-visit the current funding model with the aim of creating a more enabling environment for NGOs. 


\section{REFERENCES}

ADAMS, R. 2003. Social work and empowerment ( $3^{\text {rd }}$ ed). New York: Palgrave Macmillan.

ALGOZZINE, B. \& HANCOCK, D. 2006. Doing case study research: a practical guide for beginning researchers. New York: Teachers College.

ALIBER, M. 2003. Chronic poverty in South Africa: Indices, Causes and Policies. Human Sciences and Research Council: World Development, 31, 3, 473-490.

ARCHLEY, R. \& BARUSCH, S. 2004. Social forces of aging: an introduction into social gerontology $\left(10^{\text {th }}\right.$ ed.). Belmont: Thompson Wadsworth.

BICK, L. 2011. Not always above board. The Times, 18 November, 2.

BHAGWAN, R. 2010. The interconnection of spirituality and social development: themes for education. Social Work/Maatskaplike Werk, 46(2):164-174.

CANDA, E. 2006. The significance of spirituality for resilient response to chronic illness: a qualitative study of adults with cystic fibrosis. In: SALEEBEY, D. (ed) The strengths perspective in social work practice $\left(4^{\text {th }} \mathrm{ed}\right)$. Boston: Pearson Education: 61-76.

CHAUKE, A. 2011. Rural charities hit the big Lotto jackpot: drastic measures to be taken on funding. The Times, 22 June, 1.

DEVELOPMENT INDICATORS 2009. The presidency, Republic of South Africa. [Online] Available: www.thepresidency.gov.za/learning/me/indicators/pdf. [Retrieved: 12/05/2011].

DU BOIS, B. \& MILEY, K.K. 2011. Social work: an empowering profession. ( $7^{\text {th }}$ ed). International edition. Boston, Massachusetts:Pearson.

DU PLESSIS, C. 2011a. Centre "under-funded" Ill-fated home for the elderly was "running on a deficit every month". The Times, 15 June, 6.

DU PLESSIS, C. 2011b. "Stop starving the poor": Court rules that under-funding of non-profit bodies is unconstitutional. The Times, 22 June, 6 .

GOLDSTEIN, W. \& MANDELA, D. 2003. African soul talk: when politics is not enough. Houghton: Jacana.

GOLDSTEIN, W. 2010. A Government of compassion. Sunday Times, 7 February, 9.

HUMAN SCIENCES RESEARCH COUNCIL. 2008. Fact sheet: Poverty in South Africa. Pretoria: CIS centre.

IFE, J. 2002. Community development: community based alternatives in an age of globalization $\left(2^{\text {nd }}\right.$ ed). Frenchs Forest: Pearson Education.

INTEGRATED SERVICE DELIVERY MODEL: TOWARDS IMPROVED SOCIAL SERVICES. 2006. Pretoria: Government Printers.

KELLY, K. 2006. Calling it a day: reaching conclusions in qualitative research. In: TERRE BLANCHE, M., DURRHEIM, K. \& PAINTER, D. (eds) Research in practice: applied methods for the social sciences $\left(2^{\text {nd }}\right.$ ed). Cape Town, South Africa: University of Cape Town Press: 370-387.

KINGDON, G. \& KNIGHT, J. 2005. Unemployment in South Africa, 1995-2005 - causes, problems and policies. Southern African Regional Poverty Network. Pretoria: Economic and Social Research Council. 
KIRST-ASHMAN, K. 2007. An introduction to social work and social welfare: a critical thinking perspective $\left(2^{\text {nd }}\right.$ ed). Belmont, California: Thompson Brooks/Cole.

KOWALSKI, R. \& LEARY, M. 2004. The interface of social and clinical psychology: key readings. New York: Psychology Press.

NATIONAL PLANNING COMMISSION. 2011. Towards a National Development Plan. The Presidency: Republic of South Africa. [Online] Available: www.NPConline.co.za. [Retrieved: 22/06/2011].

NIELSEN, W. 1972. The big foundations: a twentieth century fund study. New York: Columbia University Press.

OLDER PERSON'S ACT. 2006. Vol. 497, No. 29346. Pretoria: Government Printing Works.

O’LEARY, Z. 2005. The essential guide to doing research. London: Sage Publication.

PATEL, L. 2005. Social welfare and social development in South Africa. Cape Town: Oxford University Press.

PHILP, P. 2009. Charities going bust as recession hits: suffer, little children. Sunday Times, 2.

PINCH, S. 1997. Worlds of welfare: understanding the changing geographies of social welfare provision. London: Routledge.

PRETORIUS, T. \& DE LA REY, C. 2004. A brief introduction into research approaches in psychology. In: SCHWARTZ, L., DE LA REY, C. \& DUNCAN, N. (eds) Psychology: an introduction. Cape Town: Oxford University Press.

QUARTERLY LABOUR FORCE SURVEY: QUARTER 1. 2011. Pretoria: Statistics South Africa.

RAMAPHOSA, C. 2011. Come together to build a better future. Sunday Times, 12 June, 4.

SALEEBY, D. (ed) 2006. The strengths perspective in social work practice $\left(4^{\text {th }}\right.$ ed). Boston: Pearson Education.

SHULMAN, L. 2006. The skills of helping: individuals, families, groups and communities. Belmont: Thompson-Brookes/Cole.

SIBANDA, J. 2009. How funding affects service delivery among non-profit organisations in Johannesburg. Johannesburg: University of the Witwatersrand. (MA thesis in Social Development)

SWILLING, M. \& RUSSELL, B. 2002. The size and scope of non-profit sector in South Africa. Durban: Knoxville Printers.

TERRE'BLANCHE, M., DURRHEIM, K. \& KELLY, K. 2006. First steps in qualitative data analysis. In: TERRE'BLANCHE, M. \& PAINTER, D. (eds) Research in practice: applied methods for social sciences $\left(2^{\text {nd }}\right.$ ed). Cape Town: University of Cape Town Press: 322-344.

TRACY, J. 2002. J.K. Lasser's financial basics for business managers. New York: John Wiley \& Sons.

VAN DER MERWE, W., SWART, I. \& HENDRICKS, J. 2009. Faith-based organisations in the context of social welfare and development in South Africa: towards conceptualization. Social Work/Maatskaplike Werk, 45(2):125-139. 
VOLLGRAAFF, R. 2011a. First-quarter growth rate "unsustainable". Sunday Times Business Times, 12 June, 4.

VOLLGRAAFF, R. 2011b. Manuel and Patel "share same vision”. Sunday Times, 12 June, 8. WEBER, S. 1990. Content analysis. London: Sage Publications.

WEYERS, M. 2001. The theory and practice of community work: a South African perspective. Potchefstroom: Keurkopie.

WHITE PAPER FOR SOCIAL WELFARE. 1997. Pretoria: Government Printers.

WiILLIAMS, M., UNRAU, Y.A., GRINNELL, R.M. \& EPSTEIN, I. 2011. The qualitative research approach. In: GRINNELL, R.M. \& UNRAU, Y.A. (eds) Social work research and evaluation: foundations of evidence-based practice $\left(9^{\text {th }}\right.$ ed). New York: Oxford University Press: 52-67.

Ms Refilwe Nyandeni, Department of Social Work, School of Human and Community Development, Faculty of Humanities, University of the Witwatersrand; Prof Eleanor Ross, Centre for Social Development in Africa, University of Johannesburg, Johannesburg, South Africa. 